\title{
Patterns of mortality in second generation Irish living in England and Wales: longitudinal study
}

\author{
S Harding, R Balarajan
}

\section{Abstract}

Objective-To examine the mortality of second generation Irish living in England and Wales.

Design-Longitudinal study of $1 \%$ of the population of England and Wales (longitudinal study by the Office of Population Censuses and Surveys (now the Office for National Statistics)) followed up from 1971 to 1989.

Subjects-3075 men and 3233 women aged 15 and over in 1971.

Main outcome measures-Age and sex specific standardised mortality ratios for all causes, cancers, coronary heart disease, cerebrovascular diseases, respiratory diseases, and injuries and poisonings. Deaths were also analysed by socioeconomic indicators.

Results-786 deaths were traced to men and 762 to women. At working ages (men, aged 15-64; women, 15-59) the mortality of men (standardised mortality ratio 126) and women (129) was significantly higher than that of all men and all women. At ages 15-44, relative disadvantages were even greater both for men (145) and for women (164). Mortality was raised for most major causes of death. Significant excess mortality from cancers was seen for men of working age (132) and for women aged 60 and over (122). At working ages mortality of the second generation Irish in every social class and in the categories of car access and housing tenure was higher than that of all men and all women in the corresponding categories. Adjusting for these socioeconomic indicators did not explain the excess mortality.

Conclusion-Mortality of second generation Irish men and women was higher than that of all men and all women and for most major causes of death. While socioeconomic factors remain important, cultural and lifestyle factors are likely to contribute to this adverse mortality.

\section{Introduction}

The Irish born population in England and Wales, estimated at $2 \%$ of the population (just over 750000 ), is the largest migrant group. ${ }^{1}$ The health needs of these people, however, remain relatively underresearched. The last national analysis by country of birth showed that the mortality of Irish people was higher than that of all other migrant groups. ${ }^{2}$ Young adults, particularly men, showed even higher mortality. For all major causes of death, Irish born people showed adverse mortality risks compared with the host population.

Migrant studies, such as those of Japanese people in the United States and of Polish people in England and Wales, have shown that patterns of mortality converge over time with those of the host population. ${ }^{34}$ As people become exposed to similar environmental influences, risk of disease shifts towards that of the host country. Migration of the Irish to England and Wales has been long standing, with two main peaks, around 1861 and $1961,{ }^{5}$ so we expect the second generation Irish to be a sizeable ethnic group. In this context, the patterns of mortality of the second generation Irish should be similar to those of the population in England and Wales.
Using the longitudinal study by the Office of Population Censuses and Surveys (now the Office for National Statistics), we examined the mortality of the Irish who were born in England and Wales.

\section{Methods}

The longitudinal study is a record linkage study containing a $1 \%$ sample of the population of England and Wales born on one of four selected birth dates. The initial sample was drawn from the 1971 census and traced at the NHS Central Register. The study sample is continually updated by linking information from the record systems that routinely record date of birth. These include births, deaths, migrations, and information from subsequent censuses. Details of the study are discussed elsewhere. ${ }^{6}$

Country of birth was recorded in the 1971 census, the only decennial census to include country of birth of parents. This provided a unique opportunity to identify people born in England and Wales (aged 15 years and over at the 1971 Census) to parents born in the Republic of Ireland. Parents born in Northern Ireland could not be identified as they were coded as born in the United Kingdom. Overall findings are presented by father, mother, or both parents born in Ireland. Because of the limitation of sample size on disaggregation, however, most of the detailed results presented are for those with at least one parent born in the Republic of Ireland.

We analysed deaths during the follow up period 1971 to 1989 . On the basis of person years at risk, we derived sex specific standardised mortality ratios for all causes, all cancers, lung cancer, ischaemic heart disease, cerebrovascular diseases, respiratory diseases, and injuries and poisonings, adjusted for age and calendar period. ${ }^{7}$ The standard rates were age, sex, and cause specific rates of the whole longitudinal study's sample. Findings presented at working ages refer to age adjusted mortality of men aged 15-64 and women aged 15-59.

We examined the influences of varying socioeconomic distributions by repeating the analysis and standardising for social class (according to occupation), for access to a car, and for housing tenure at the 1971

Table 1-Age adjusted standardised mortality ratios (95\% confidence interval), ${ }^{*} 1971-89$, of second generation Irish living in England and Wales

\begin{tabular}{lcc}
\hline $\begin{array}{l}\text { Age at death } \\
\text { (years) }\end{array}$ & No of deaths & Standardised mortality ratio \\
\hline Men: & & \\
$15-44$ & 46 & $145(106$ to 194$) \dagger$ \\
$45-64$ & 194 & $122(106$ to 141$) \dagger$ \\
$65-74$ & 270 & $119(105$ to 134$) \dagger$ \\
$\geqslant 75$ & 276 & $95(84$ to 107$)$ \\
$\geqslant 15$ & 786 & $111(103$ to 119$) \dagger$ \\
Women: & & \\
$15-44$ & 32 & $164(112$ to 232$) \dagger$ \\
$45-59$ & 62 & $116(89$ to 148$)$ \\
$60-74$ & 209 & $112(97$ to 128$)$ \\
$\geqslant 75$ & 459 & $112(102$ to 123$) \dagger$ \\
$\geqslant 15$ & 762 & $114(106$ to 122$) \dagger$ \\
\hline
\end{tabular}

*Relative to all men (standardised mortality ratio $=100$ ), all women (100).

tStandardised mortality ratio significantly different from 100 
Table 2-Age adjusted standardised mortality ratios (95\% confidence interval), ${ }^{*} 1971$ 89, of second generation Irish aged 15 and over living in England and Wales, by mother, father, or both parents born in Ireland

\begin{tabular}{|c|c|c|c|c|}
\hline & \multicolumn{2}{|r|}{ Men } & \multicolumn{2}{|c|}{ Women } \\
\hline & $\begin{array}{l}\text { No of } \\
\text { deaths }\end{array}$ & $\begin{array}{l}\text { Standardised } \\
\text { mortality ratio }\end{array}$ & $\begin{array}{l}\text { No of } \\
\text { deaths }\end{array}$ & $\begin{array}{l}\text { Standardised } \\
\text { mortality ratio }\end{array}$ \\
\hline Irish born mother & 287 & 111 (99 to 125$)$ & 231 & 104 (91 to 119$)$ \\
\hline $\begin{array}{l}\text { Irish born father } \\
\text { Irish born mother and }\end{array}$ & 348 & 105 (94 to 117$)$ & 377 & 117 (105 to 129$) \dagger$ \\
\hline $\begin{array}{l}\text { father } \\
\text { Either or both parents }\end{array}$ & 151 & $128(109$ to 150$) \dagger$ & 154 & $123(105$ to 144$) \dagger$ \\
\hline $\begin{array}{l}\text { born in Ireland } \\
\chi^{2}(1 \mathrm{df}) \ddagger \\
P \text { value }\end{array}$ & 786 & $\begin{array}{c}111(103 \text { to } 119) \dagger \\
3.57 \\
0.06\end{array}$ & 762 & $\begin{array}{c}114 \text { (106 to 122) } \dagger \\
1.12 \\
0.29\end{array}$ \\
\hline
\end{tabular}

"Relative to all men (standardised mortality ratio=100), all women (100).

†Standardised mortality ratio significantly different from 100 .

¥One parent compared with both parents born in Ireland. than in the host population ( $53 \%$ men, $47 \%$ women) in 1971. The younger age distribution of the second generation Irish reflects the function of time of migration of their parents. During the period of follow up 1971-89, 1548 deaths (786 to men, 762 to women) occurred among the second generation Irish.

AGE ADJUSTED MORTALITY

Table 1 shows significantly higher mortality of second generation Irish men and women. Mortality excesses were greater at younger working ages (15-44) than at older ages, with greater excesses among women than among men. At the oldest ages (75 and over), women continued to show significantly higher mortality than that of all women.

Mortality varied depending on whether one or both parents were born in Ireland. Table 2 shows that the summary measure, based on those with at least one parent born in Ireland, may underestimate the mortality disadvantage of those with both parents born in Ireland. The difference between the standardised mortality ratios, however, did not reach formal significance. social class.

In the longitudinal study survivors who cannot be found through a registered event or at a subsequent census are assumed to be lost to follow up. Losses among the second generation Irish (8\% of men and $7 \%$ of women) were slightly higher than for all men $(6 \%)$ and all women $(5 \%)$ by the end of the study period. No evidence was found of a systematic bias in terms of socioeconomic characteristics of those missing, which suggests that the impact on the mortality estimates is negligible.

\section{Results}

We identified 6308 second generation Irish (3075 men, 3233 women) who were aged 15 and over at the 1971 census and traced at the National Health Service Central Register. This sample showed higher proportions of people aged $15-44$ (63\% men, $57 \%$ women)

\section{CAUSE SPECIFIC MORTALITY}

Table 3 shows a pattern of higher mortality from most major causes except cerebrovascular diseases for men and injuries and poisonings for women. Significantly higher mortality from all cancers and lung cancer is seen for men at working ages (15-64) and for women aged 60 and over. At these older ages women also showed a significant excess of deaths from respiratory diseases. Higher mortality from "other cancers" was also evident among women and peaked at ages 35-44 (standardised mortality ratio 217 (95\% confidence interval 104 to 398)).

\section{SOCIOECONOMIC DIFFERENCES IN MORTALITY}

Table 4 shows higher mortality of second generation Irish men in every social class compared with all men in

Table 3-Cause specific standardised mortality ratios (95\% confidence interval), ${ }^{*} 1971-89$, of second generation Irish living in England and Wales

\begin{tabular}{|c|c|c|c|c|c|c|}
\hline & \multicolumn{6}{|c|}{ Age at death (years) } \\
\hline & \multicolumn{2}{|c|}{$15-64 t$} & \multicolumn{2}{|r|}{$\geqslant 65 \ddagger$} & \multicolumn{2}{|r|}{$\geqslant 15$} \\
\hline & $\begin{array}{l}\text { No of } \\
\text { deaths }\end{array}$ & $\begin{array}{l}\text { Standardised } \\
\text { mortality ratio }\end{array}$ & $\begin{array}{l}\text { No of } \\
\text { deaths }\end{array}$ & $\begin{array}{l}\text { Standardised } \\
\text { mortality ratio }\end{array}$ & $\begin{array}{l}\text { No of } \\
\text { deaths }\end{array}$ & $\begin{array}{l}\text { Standardised } \\
\text { mortality ratio }\end{array}$ \\
\hline \multicolumn{7}{|l|}{ Men } \\
\hline All cancers: & 72 & 132 (103 to 166$) \S$ & 123 & $105(88$ to 126$)$ & 195 & 114 (99 to 131) \\
\hline Lung cancer & 32 & 152 (104 to 214$) \S$ & 44 & 103 (75 to 138$)$ & 76 & 119 (94 to 149$)$ \\
\hline Other cancers & 40 & $120(86$ to 163$)$ & 79 & 107 (85 to 134) & 119 & 111 (92 to 133) \\
\hline Ischaemic heart disease & 74 & 114 (89 to 143 ) & 171 & 110 (94 to 127$)$ & 245 & 111 (97 to 126$)$ \\
\hline Cerebrovascular diseases & 8 & 70 (30 to 137) & 57 & 96 (72 to 124$)$ & 65 & 91 (71 to 116$)$ \\
\hline Respiratory diseases & 16 & $122(70$ to 199$)$ & 94 & 114 (92 to 139$)$ & 110 & 115 (95 to 139$)$ \\
\hline Injuries and poisonings: & 26 & 140 (92 to 206$)$ & 7 & 94 (38 to 193) & 33 & $127(87$ to 178$)$ \\
\hline Suicidesף & 10 & 145 (70 to 266$)$ & 0 & 0 & 10 & $115(55$ to 211$)$ \\
\hline Injuries & 16 & $138(79$ to 224$)$ & 7 & $123(50$ to 254$)$ & 23 & $133(84$ to 200$)$ \\
\hline All causes & 240 & 126 (111 to 143$) \S$ & 546 & 105 (97 to 115$)$ & 786 & 111 (103 to 119$) \S$ \\
\hline \multicolumn{7}{|l|}{ Women } \\
\hline All cancers: & 45 & $133(97$ to 178$)$ & 136 & 122 (102 to 144$) \S$ & 181 & $124(107$ to 144$) \S$ \\
\hline Lung cancer & 6 & 136 (50 to 297$)$ & 25 & 157 (102 to 232$) \S$ & 31 & 153 (104 to 217$) \S$ \\
\hline Other cancers & 39 & $132(94$ to 181$)$ & 111 & 116 (95 to 139) & 150 & $120(101$ to 140$) \S$ \\
\hline Ischaemic heart disease & 9 & $102(47$ to 193$)$ & 161 & 109 (92 to 127$)$ & 170 & 108 (93 to 126$)$ \\
\hline Cerebrovascular diseases & 4 & 78 (21 to 201$)$ & 106 & $106(87$ to 128$)$ & 110 & 105 (86 to 126$)$ \\
\hline Respiratory diseases & 4 & 94 (26 to 241$)$ & 100 & 134 (109 to 163$) \S$ & 104 & $132(108$ to 160$) \S$ \\
\hline Injuries and poisonings: & 10 & 148 (71 to 273$)$ & 8 & $67(29$ to 131$)$ & 18 & 96 (57 to 151) \\
\hline Suicidesף & 4 & 125 (34 to 321$)$ & 0 & 0 & 4 & 76 (21 to 195$)$ \\
\hline Injuries & 6 & 169 (62 to 368$)$ & 8 & 80 (34 to 157$)$ & 14 & $103(56$ to 173$)$ \\
\hline All causes & 94 & 129 (104 to 157$) \S$ & 668 & $112(104$ to 121$) \S$ & 762 & 114 (106 to 122$) \S$ \\
\hline
\end{tabular}

*Relative to all men (standardised mortality ratio=100), all women (100).

†Age 15-59 for women.

†Age 60 and over for women.

$\S$ Standardised mortality ratio significantly different from 100

IIncludes undetermined deaths. 
Table 4-All cause standardised mortality ratios (95\% confidence interval)* for all men and all women and second generation Irish men and women at working ages, $t$ by social class, car access, and housing tenure at the 1971 census, and mortality standardised for these measures

\begin{tabular}{|c|c|c|c|c|c|c|c|c|}
\hline & \multicolumn{2}{|r|}{ All men } & \multicolumn{2}{|c|}{$\begin{array}{l}\text { Second generation } \\
\text { Irish men }\end{array}$} & \multicolumn{2}{|r|}{ All women } & \multicolumn{2}{|c|}{$\begin{array}{l}\text { Second generation } \\
\text { Irish women }\end{array}$} \\
\hline & $\begin{array}{l}\text { No of } \\
\text { deaths }\end{array}$ & $\begin{array}{l}\text { Standardised } \\
\text { mortality ratio }\end{array}$ & $\begin{array}{l}\text { No of } \\
\text { deaths }\end{array}$ & $\begin{array}{l}\text { Standardised } \\
\text { mortality ratio }\end{array}$ & $\begin{array}{l}\text { No of } \\
\text { deaths }\end{array}$ & $\begin{array}{l}\text { Standardised } \\
\text { mortality ratio }\end{array}$ & $\begin{array}{l}\text { No of } \\
\text { deaths }\end{array}$ & $\begin{array}{l}\text { Standardised } \\
\text { mortality ratio }\end{array}$ \\
\hline \multicolumn{9}{|l|}{ Social class $¥$} \\
\hline I and II & 1874 & $76(73$ to 80$) \S$ & 30 & 90 (61 to 129$)$ & 650 & 76 (70 to 82$) \S$ & 9 & 74 (34 to 141$)$ \\
\hline III Non-manual & 1018 & $97(91$ to 104$)$ & 27 & 168 (111 to 244$) \S n$ & 451 & 90 (82 to 99$) \S$ & 7 & $73(29$ to 150$)$ \\
\hline III Manual & 3681 & 99 (96 to 102$)$ & 57 & 126 (96 to 164$)$ & 1162 & 101 (95 to 107$)$ & 23 & 166 (105 to 248$) \S n$ \\
\hline IV and V & 2721 & 117 (113 to 122$) \S$ & 48 & 143 (105 to 189$) \S$ & 813 & $113(105$ to 121$) \S$ & 18 & 182 (108 to 287$) \S$ \\
\hline $\begin{array}{l}\text { Mortality standardised for social class } \\
\text { Housing tenure } \\
\text { Access to car: }\end{array}$ & & 100 & & $132(112$ to 154$) \S$ & & 100 & & 130 (99 to 170$)$ \\
\hline Owner occupier & 4438 & $77(75$ to 80$) \S$ & 57 & 84 (64 to 109$)$ & 1620 & 77 (73 to 81$) \S$ & 26 & 94 (62 to 138$)$ \\
\hline Tenant, local authority & 2265 & 104 (100 to 108$)$ & 41 & 138 (99 to 187 ) & 767 & $100(93$ to 107$)$ & 13 & 138 (73 to 235$)$ \\
\hline Tenant, private sector & 1150 & 90 (85 to 96$) \S$ & 14 & $102(56$ to 171$)$ & 403 & 94 (85 to 104$)$ & 9 & 152 (69 to 288$)$ \\
\hline \multicolumn{9}{|l|}{ No access to car: } \\
\hline Owner occupier & 1657 & 108 (103 to 115$) \S$ & 26 & 131 (86 to 193 ) & 607 & $105(97$ to 114$)$ & 11 & 125 (62 to 224$)$ \\
\hline Tenant, local authority & 2761 & $131(126$ to 136$) \S$ & 66 & 156 (121 to 199$) \S$ & 1108 & $136(128$ to 145$) \S$ & 26 & 194 (127 to 285$) \S$ \\
\hline Tenant, private sector & 1328 & 135 (128 to 142$) \S$ & 31 & 193 (131 to 273$) \S$ & 449 & 125 (114 to 137$) \S$ & 7 & 95 (38 to 196$)$ \\
\hline $\begin{array}{l}\text { Mortality standardised for housing tenure } \\
\text { and car access }\end{array}$ & & 100 & & 124 (109 to 141$) \S$ & & 100 & & $126(102$ to 155$) \S$ \\
\hline
\end{tabular}

${ }^{*}$ Relative to all men (standardised mortality ratio $=100$ ), all women (100).

tMen aged 15-64, women aged 15-59 at death.

fFirst five years of follow up were excluded to allow for health selection. ${ }^{8}$

$\S$ Standardised mortality ratio significantly different from 100 .

ISignificant difference between standardised mortaity ratios of second generation Irish men and women and that of all men and women in same category, $P<0.05$.

the corresponding social class. Although the pattern of class mortality among second generation Irish men is not as consistent as for all men, a split between non-manual workers and manual workers shows a class gradient. On disaggregation of social classes IV and V, men in social class $\mathrm{V}$ (standardised mortality ratio 215 (138 to 320)) show the highest mortality. Second generation Irish women generally show a similar pattern to all women, but class differences are greater because of particularly high mortality in the manual social classes.

Mortality of the second generation Irish is also higher in most categories of tenure and car access compared with all men and all women in the same category. The pattern of mortality differences is generally similar to the host population, with lower mortality in every housing category in which occupants have access to a car than in those in which occupants have no access to a car. The only exception is women in privately rented housing without access to a car as they show lower (non-significant) mortality than all women.

At older ages similar patterns were seen for social class, with higher mortality in every class category compared with the mortality of all men and women in the corresponding classes. The same is true for mortality of women at older ages by car access and tenure, but among men mortality was similar to that among all men.

Table 5-Age adjusted standardised mortality ratios* for second generation Irish living in England and Wales, 1971-80, 1981-9

\begin{tabular}{|c|c|c|c|c|c|c|}
\hline & \multicolumn{6}{|c|}{ Age at death (years) } \\
\hline & \multicolumn{3}{|c|}{ Men } & \multicolumn{3}{|c|}{ Women } \\
\hline & $15-64$ & $65-74$ & $\geqslant 75$ & $15-59$ & $60-74$ & $\geqslant 75$ \\
\hline $1971-80$ & 113 & 112 & 89 & 128 & 110 & 113 \\
\hline $1981-9$ & 144 & 130 & 100 & 130 & 114 & 111 \\
\hline $1971-89$ & 126 & 119 & 95 & 129 & 112 & 112 \\
\hline$\chi^{2}(1 d f)$ & 3.26 & 1.39 & 0.79 & 0 & 0.04 & 0.02 \\
\hline$P$ value & 0.07 & 0.24 & 0.37 & 0 & 0.83 & 0.89 \\
\hline
\end{tabular}

*Relative to all men (standardised mortality ratio $=100$ ) and all women $(100)$.
The standardised mortality ratios adjusted both for social class and for tenure and car access at working ages (table 4) showed little or no improvement in the overall age adjusted mortality of second generation Irish men or women. Beyond working ages, age adjusted mortality ratios standardised for social class (men 110, women 109) and for car access and tenure (men 107, women 114) were similar to ratios adjusted for age only (men 105, women 112).

\section{MORTALITY DIFFERENCES BY TIME PERIOD}

No significant difference was found between the standardised mortality ratios for the 1970s and those for the 1980s (table 5). Aware that standardised mortality ratios are relative measures, we also examined the death rates. Over the two decades the death rates per person years at risk at working ages in men (1971-80, 2088; 1981-9, 2299; $\left.\chi^{2}=2.04, \mathrm{P}=0.15\right)$ and in women (1074; $\left.880 ; \chi^{2}=3.39, \mathrm{P}=0.07\right)$ did not show any significant declines. At older ages a significant decline in mortality between the decades was noted for women only.

\section{Discussion}

Explanations for the high mortality of first generation Irish migrants have centred on health selection issues. ${ }^{910}$ Ease of migration to Great Britain might have encouraged the less healthy to migrate, helping to explain why their mortality was higher than that of the Irish in the Republic of Ireland. Health selection issues are less important in explaining the mortality of second generation migrants. One previous attempt based on a shorter follow up period suggested raised all cause mortality of the second generation Irish. ${ }^{11}$ This study covers 19 years of follow up of the longitudinal study's cohort and examines in detail the cause specific mortality of the second generation Irish along with socioeconomic influences. The findings clearly show that the second generation Irish continue to experience adverse mortality risks, particularly at younger ages, and for all major causes of death. These patterns are very similar to those reported for the first generation Irish. ${ }^{2}$

It has been suggested that Irish immigration is linked to high mortality in certain urban areas in Britain through entrenched economic and cultural differences in life 


\section{Key messages}

- This study shows that second generation Irish men and women-particularly those with both parents born in Ireland-show higher mortality than all men and all women in England and Wales - Mortality is raised for most major causes of death, with a significant excess from cancers

- Adjustment for social class, car access, and housing tenure did not explain the excess in all cause mortality

- With over two million second generation Irish and growing numbers of a third generation, their health needs special consideration

chances. ${ }^{12}$ The high mortality of the second generation implies that these structural factors remain in place. Evidence exists, however, for structural assimilation as higher levels of upward occupational and educational mobility for second generation Irish compared with the English have been shown for both men and women. ${ }^{13} \mathrm{We}$ also found higher proportions of second generation Irish (men $30 \%$, women $39 \%$ ) in a non-manual social class than all longitudinal study members (men $25 \%$, women $26 \%$ ). This difference was mainly due to the larger proportion of second generation Irish in social class III non-manual, which includes clerks, cashiers, and sales assistants. However, we found lower proportions (men $54 \%$, women $54 \%$ ) with access to a car compared with all members in the longitudinal study (men 63\%, women $62 \%$ ). Although these are established indicators of the social forces affecting health and disease, ${ }^{14}$ they fail to explain the high mortality of the second generation Irish. Current work examines whether these patterns obscure intraclass differences and also the impact of changes in social circumstances on mortality in the 1980s. Lifestyle factors such as diet, smoking, and drinking among the second generation Irish also need to be explored as first generation Irish have a higher prevalence of smoking and drinking than the population in England and Wales. ${ }^{15} 16$ This raises the question of whether there has been a generational lag in lifestyle despite some structural assimilation.

In addition, the process of migration entails economic and social upheaval, breakdown of family ties, and adjustment to a new environment. ${ }^{17}{ }^{18}$ It could be argued that these factors continue to influence the total course of ill health of second generation migrants. Some argue that, unlike the positive identity of American-Irish in the United States, the identity of the Irish in England has not been supported by the Catholic church or other institutions. ${ }^{19} 20$ The unrest in Northern Ireland is likely to have added to the difficulties in promoting a positive Irish identity. The negative perception of Irishness might have created cultural pressures on the Irish to become English ${ }^{21}$ though studies of second generation Irish children showed that a sizeable proportion resisted the process of assimilation and asserted an Irish identity. ${ }^{22}$

\section{CONCLUSION}

This paper shows that the second generation Irish born in England and Wales, particularly those with both parents born in the Republic of Ireland, experience significantly higher mortality than that for England and Wales for most major causes of death. There are many factors that could contribute to this adverse experience. Though the immediate issues of migration are less important and there is a degree of structural convergence in terms of socioeconomic status, there is no reason to believe that these factors do not still operate. Furthermore, cultural and lifestyle factors are likely to have a significant role. With over two million second generation Irish ${ }^{11}$ and growing numbers of a third generation, clearly special consideration should be given to their health.

We thank Ann Bethune, Haroulla Filakti, Michael Rosato, Jillian Smith, Karen Dunnell, John Fox, and the referees for their helpful comments. Crown copyright.

Funding: No special funding.

Conflict of interest: None.

1 Office of Population Censuses and Surveys. 1991 Census: ethric group and country of birth, Great Britain. Vol 1. London: HMSO 1993.

2 Balarajan R, Bulusu L. Mortality among immigrants in England and Wales, 1979-83. In: Britton M, ed. Mortality and geography. $A$ review in the 1979-83. In: Britton M, ed. Mortality and geography.

3 Syme SI, Marmot MG, Kagan H, Rhoads, G. Epidemiologic studies of CHD and stroke in Japanese men living in Japan, Hawaii and California: CHD and stroke in Japanese men living in Japan,
introduction. $A m \mathcal{F}$ Epidemiol 1975;102:477-80.

4 Adelstein AM, Staszewski J, Muir CS. Cancer mortality in 1970-72 among Polish-born migrants to England and Wales. $\mathrm{Br}$ F Cancer 1979;40:464-75.

5 Garvey D. The history of migration flows in the Republic of Ireland. Population Trends 1985;39:22-30.

6 Hattersley L. Creeser R. Longitudinal study 1971-1991. History, organisation and quality of data. London: HMSO, 1995.

7 Goldblatt P, Jones D. Methods. In: Goldblatt P, ed. 1971-81 Longitudinal study. Mortality and social organisation. London: HMSO, 1990.

8 Fox J, Goldblatt P, Jones D. Social class mortality differentials: artifact, selection or life circumstances? In: Goldblatt P, ed. 1971-81 Longitudinal study. Mortality and social organisation. London: HMSO, 1990.

9 Marmot MG, Adelstein AM, Bulusu L. Immigrant mortality in England and Wales 1971-78. London: HMSO, 1984.

10 Adelstein AM, Marmot MG, Dean G, Bradshaw JS. Comparison of mortality of Irish immigrants in England and Wales with that of Irish and mortality of Irish immigrants in England and Wales with

11 Raftery J, Jones DR, Rosato $M$. the mortality of first and second generation Irish immigrants in the UK. Soc Sci Med 1990;31:577-84.

12 Williams R. Britain's regional mortality: a legacy from disaster in the Celtic periphery? Soc Sci Med 1994;39:189-99.

13 Hornsby-Smith $M$, Dale $A$. The assimilation of Irish immigrants in England. Br F Sociol 1988;39:519-43.

14 Goldblatt P. Mortality and alternative social classifications. In Goldblatt P, ed. 1971-81 Longitudinal study. Mortality and social organisation. London: HMSO, 1990.

15 Balarajan R, Yuen P. British smoking and drinking habits: variation by country of birth. Community Medicine 1986;8:237-94.

16 Harding S, Allen E. Sources and uses of data on cancer among ethnic groups. Proceedings of Cancer Research Campaign and Department of Health conference, 1995. Br 7 Cancer (in press).

17 Hull D. Migration, adaptation and illness: a review. Soc Sci Med 1979; 13A:25-36.

18 Marmot M. Culture and illness: epidemiological evidence. In: Christie MJ, Mellet P, eds. Foundations of psychosomatics. New York: John Wiley, 1981.

19 Hickman MJ. The Irish in Britain: racism, incorporation and identity. Irish Studies Review 1995;10:16-9.

20 Kellagher D. The health of the Irish in Britain. In: Kellagher D, Hillier S, eds. Researching cultural differences in health. London: Routledge, 1996 (in press).

21 Hickman MJ. Religion, class and identity. Aldershot: Avbury, 1995.

22 Ullah P. Second generation Irish youth: identity and ethnicity. New Community 1985; x:310-20.

(Accepted 14 March 1996)

\section{Corrections}

\section{Randomised study of $\mathbf{n}$ of 1 trials versus standard} practice

A potentially important error occurred in this paper by Jeffrey Mahon and colleagues (27 April, pp 1069-74). The authors cited the wrong reference at number 21 (concerned with the argument that the minimal clinically important difference for $\mathrm{n}$ of 1 trials shown by a seven point Likert scale is a mean change of 0.5 per symptom). The correct reference is:

21 Jaeschke R, Guyatt GH, Keller J, Singer J. Interpreting changes in qualityof-life score in n of 1 randomized trials. Control Clin Trials 1991;12: 226-33S.

\section{Ranitidine and aseptic meningitis}

Owing to an editorial error the names of two authors were omitted from this drug point by J $M$ Durand and $L$ Suchet (6 April, p 886). The two other authors were Sophie Morange from the department of toxicology and Bernard Michel from the department of neurology at the Sainte-Marguerite Hospital in Marseilles, France. 